\title{
The eZoomBook Tool: A Blended and Eclectic Approach to Digital Pedagogy
}

\author{
Christine Evain ${ }^{1}$, Chris De Marco ${ }^{2}$ \\ ${ }^{1}$ University of Rennes 2, LIDILE laboratory, France \\ ${ }^{2}$ Audencia Research, France \\ Correspondence: Christine Evain, University of Rennes 2, LIDILE laboratory, France.
}

$\begin{array}{lrr}\text { Received: May 14, } 2018 & \text { Accepted: June 11, 2018 } & \text { Online Published: July 9, } 2018 \\ \text { doi:10.11114/jets.v6i8.3428 } & \text { URL: https://doi.org/10.11114/jets.v6i8.3428 }\end{array}$

\begin{abstract}
This article is a comparative study of five pedagogical experiments that involved the use of the digital eZoomBook tool. An "eZoomBook" is a customized multi-level document incorporating links among the different layers that are accessible by tabs in a menu. eZoomBooks include a zooming in and out function allowing readers to navigate easily among the different layers. Each of the five experiments is examined in light of six classroom variables. We aim to demonstrate that the eZoomBook editor facilitates a blended, eclectic approach adaptable to a variety of pedagogical contexts and highly motivating for its users.
\end{abstract}

Keywords: digital tools, collaborative project, blended learning, second language acquisition, multi-layered documents, personalizable virtual documents, eZoomBook

\section{Introduction}

Since the development of the eZoomBook digital tool at the Ecole Centrale research laboratory in 2010, our team of researchers has collaborated with classroom teachers to determine the validity of the tool, develop a coherent and pertinent methodology, and assess the pedagogical benefit of the tool within a wide range of classroom contexts. In our previous articles on eZB in the human sciences alone (Note 1) we have shown how eZoomBook-empowered pedagogical projects have yielded significant results, enhancing workflow efficiency, increasing student motivation, and strengthening distance communication, partnerships and teamwork. In this article, we will synthesize the results of five experiments to show how the tool is a versatile and effective complement to a wide variety of classroom environments.

Developed by researchers at the Ecole Centrale de Nantes School of Engineering, the eZB editor creates a learner-friendly experience in reading. Its vocation is to enhance the reading experience through pedagogical exercises that allow contributors to collaboratively create and share multi-level books called "eZoomBooks". eZoombooks are abridged versions of the original document made accessible by a zooming function and enriched by a number of add-ons specific to learner objectives. Each contributor-produced version is a different layer superimposed on the original book. We were thus able to start a collection of eZBs mostly related to English literature where each eZB was a unique development of user-generated layers.

Due to technical difficulties, these user-generated eZBs created under a Creative Commons license were unavailable to the broad public. We thus decided to post the open-source eZB editor on our research blog and allow anyone to download it and use it for the creation of eZBs. As a result, and mainly through the partnership of the Nantes Academy of Education, the open-sourced eZB editor can be extended to all pedagogical projects from primary school to university education and continuous training which are based on a text (contributor-produced or not) or a full corpus.

The eZoomBook complements c

lassroom teaching and facilitates a blended-learning approach combining online digital media with traditional classroom methods. The eZB editor makes it possible to create interactive documents for the creation of multimedia enrichments and activities as well as multiple abridged versions of a given document through a Wiki-like system of construction. The educational perspectives of the eZB have been highlighted by a range of experiments carried out in different learning environments (De Marco, C., Evain C., and Gutierrez F. 2013, Evain, C., De Marco, C. 2013, 2014, 2015, 2016a, 2016b, and S. Carolan 2013, 2014). 
For example, in our article "Making Teaching Visible to Learners through the eZoomBook Platform" (2015), we drew upon the results of John Hattie's 2009 meta study on what works best for student achievement (Hattie, 2009; Hattie and Yates, 2014). We noted that the areas that seemed to matter most in Hattie's findings, namely, reading, micro tutoring, feedback, were precisely those best exploited by the eZB methodology. In the article entitled "eZoomBook methodology and template, a case study of collective authorship in the classroom", we argued that eZB promoted collaborative work, which was beneficial on two accounts: firstly, in terms of increasing student motivation, and secondly in terms of enhancing collaborative learning. The goal of collectively producing a finished and original product in the form of an electronic document shared outside of the classroom is highly motivating to learners. The pride of producing a collective work shared and commented on by others is a pedagogical benefit of the methodology.

To demonstrate the flexibility of the tool adaptable to a variety of classroom contexts, we will summarize five pedagogical experiments showing how the eZoomBook methodology was applied in context-specific ways. To demonstrate the openness and ease of adapting the tool, we will describe its use in five very different classroom contexts. Each learning situation will be mapped in a table of specifications to illustrate examples of adaptation of the approach to varied learning contexts.

We will start by outlining our general pedagogical approach, which is intrinsically blended and eclectic in the broad meaning of the term. For us, the eclectic approach is a means to adapt teaching to the needs of specific learners within well-defined learning contexts. The importance in the approach is finding what works best in a given situation and using the various techniques and methodologies available to achieve learning goals. The context of situation is thus what defines how we teach. The eZB tool allows for an integrated approach to teaching in that it provides the means for adaptive, modular, and differentiated activities across a variety of learning contexts.

\section{How the eZB Methodology Fosters a Blended, Eclectic Approach}

As mentioned above the eZB tool provides the teacher and learner a means to personalize and adapt documents and texts so that they respond to the needs of the learner and of the learning objectives. A number of benefits accrue from the methodology.

- It makes the learning activity visible:

In our article "Making Teaching Visible to Learners through the eZoomBook Platform" (2015), we showed how the use of the platform and pedagogy increased the expectation factor and gave students more confidence and awareness of their strengths and weaknesses: "Our objective is to make the learning process come into focus and therefore increase student perception of learning as process. Visible learning is an important component of becoming lifelong learners - something we want students to recognize and value." (2015)

- It facilitates project based group learning activities:

The eZB tool is only one of the many digital tools at our disposal for project-based learning, collaborative writing and educational research. As we have pointed out in our previous articles, this area has raised a lot of interest among language researchers and teachers over the past few years (e.g., Laurillard 2008, 2012; Brewster, 2007; Lindberg \& Olofsson, 2010, Romainville \& Michaut, 2012). In executive education classes, where participants need to establish links between the training received and their professional activity, the use of Web 2.0 tools is essential because not only does it enhance workflow efficiency, it also allows distance communication, partnerships and teamwork.

- It provides flexible guidelines for an individualized approach:

Influenced by the methodology for collaborative learning described by Cassany (2008) and by Johnson and Johnson (1997), the eZB tool and teaching approach offer the following advantages.

The existence of positive group interdependence and shared individual responsibility; The students' collaboration must result in a finished product and each participant contributes to the collective effort of building up an eZB.

The possibility for the formation of heterogeneous groups in terms of skills and competencies with expert readers helping non-expert or more reluctant readers.

The enhancement of interpersonal communication skills (verbal and non-verbal) through the presentation of students' work and the assembling of the final eZB.

The meta-cognitive group work during which students verbalize the processes underlying their understanding of the content and themes of texts and receive feedback from their peers to which they have to respond.

- It gives students opportunity for peer-to-peer teaching: 
"The best way to show that you know something is to try to teach it to someone else". This idea is not new and it has inspired many practitioners from Andrew Bell's 1795 mutual teaching method to Jean-Pol Martin's (1985) learning by teaching (Lernen durch Lehren, 'LdL') methodology, expanded on by Grzega and Schoner (2008). However, such a reversal of roles implies a conception of a classroom methodology that moves towards a more cooperative and collaborative model encompassing teacher-guided peer to peer interaction." (Bellay, Evain, de Marco, 2017)

- The tool makes it possible to produce personalizable virtual documents (PVD):

Researchers are showing an interest in PVD's seeking to measure their user effectiveness (Brusilovsky, Stock, \& Strapparava, 2000, Falquet, Nerima \& Ziswiler, 2004, Falquet \& Ziswiler, 2005). "Hyperlinks and multimedia in their PVDs either provide additional information or record possible interpretation, or both. In the same way, the eZB approach allows for the personalization of documents, offering a multimedia customizable 'elegant organization' approach. The advantage of the eZB template is the zooming in and out functionalities to navigate among different levels of abridgements/enrichments and the full version of a document. In addition, like all PVDs, the eZB addresses the problems of teaching heterogeneous groups by allowing leaners to use documents suited to their levels and needs." (Evain, De Marco, 2015)

To sum up, the eZB approach is eclectic because it offers context-dependent choices from among a number of individual and group activities consistent with the needs and interests of the learners. The methodology necessarily combines the eZB digital tool with traditional classroom methods in a blended format. The framework can be adapted to many different situations and responds in particular to the following pedagogical criteria:

- the need for the teacher to structure the task with various degrees of flexibility depending on the student profile, student level and subject matter;

- the focused problem-solving nature of the student input;

- the responsibility that comes from assigned roles;

- the added motivation in completing the production of an original group project that will be publicly displayed in a virtual format.

\section{Results: Mapping out Five eZB Experiments Relative to Six Classroom Context Variables}

We will now describe the five eZB experiments in which the eZB tool figured prominently. We will describe how the tool was adapted to each of the contexts and situations using six classroom variables. The following horizontal line, applied to each of the five eZB experiments, shows the mapping.

Table 1. Six-variable mapping of eZB pedagogies

\begin{tabular}{l}
\hline \\
$\quad \begin{array}{l}\text { Original text(s) Structure Student In-class or Single or Final output } \\
\text { and guidelines input homework multidisciplinary }\end{array}$ \\
\hline $\begin{array}{l}\text { Learning situation 1 } \\
\text { Learning situation 2, } \\
\text { etc. }\end{array}$
\end{tabular}

Primary School children in a French program: "The Wolf and the Lamb"

This eZB workshop lasted a full term. Participants were children aged 8 to 10 . The goal was to introduce rewriting a text, showing the interconnection between similar or related works of literature (inter-textuality, and the differences of interpretation that arise from different versions. To do so, the teacher chose three different versions of the fable "The Wolf and the Lamb". In addition to the most famous La Fontaine version, the teacher juxtaposed two other versions. The classroom activities included the following:

- rewriting of the story,

- illustrating the fables,

- recording the fable in different languages.

There was practically no homework given in relation to the project except the collection of more recordings in different languages. This benefit of the recording activity gave the class exposure to foreign languages and showed how the moral lesson of the fable translates into different cultural contexts.

\section{Results}

The collaborative eZB produced at the conclusion of the semester was a means to record and highlight the children's 
work. When assembling the production, the different layers were defined, and arranged so that they presented themselves as tabs that also served as a table of contents.

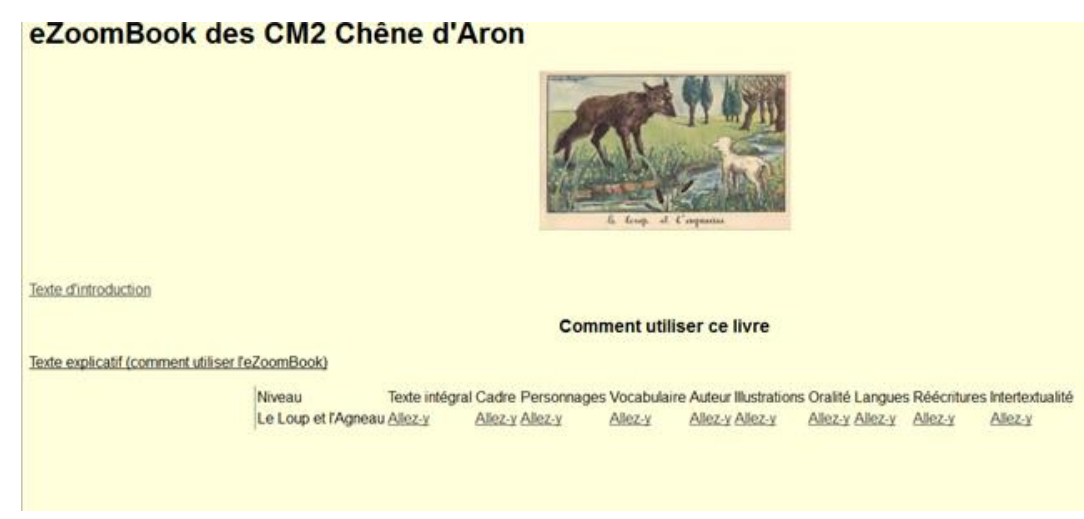

Figure 1. Table of Content of the Fable eZB

Beyond the reading, grammar and vocabulary objectives, the project allowed students to participate in the illustration of the fable (illustration 2) and the rewriting of a fable and to become aware of all the possibilities in rewriting, including the creation of a new version of the story where the meaning of the original text is purposely inverted.

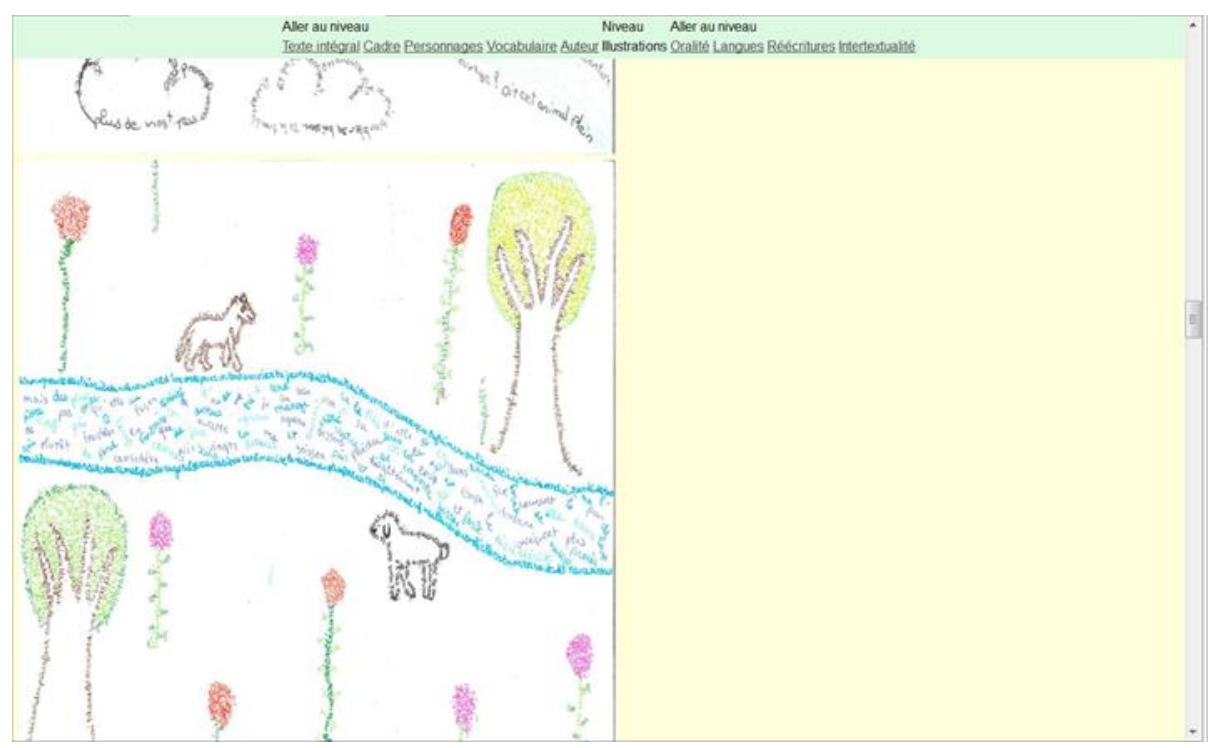

Figure 2. eZB Screenshot of an illustration of the Fable

This example shows how it is possible to create an eZoomBook after the launch and realization of class activities. In this experimentation, the teacher had total freedom to add to the pedagogical content in the course of the semester. The student input (rewritings, illustrations, recordings, etc.) was pre-defined, but not all workshop activities were carried out in class. Many recordings were done in the home context, affording parents opportunities to participate in the creation of an eZoomBook. At the conclusion of the semester, all of the student contributions were uploaded into the eZoomBook template.

\section{Primary School children: "Each Peach Pear Plum" (English program)}

An eZoomBook based on the book "Each Peach Pear Plum" by Janet and Alan Ahlberg (2004) was developed to guide French primary school pupils (ranging in ages from 7 to 9) in some short and easy exercises in English. This example shows how it is possible to use an eZoomBook with a pre-constructed structure and guidelines in a blended learning context. The student input (rhyme-matching game, illustrations, recordings, etc.) was pre-defined. All of the workshop activities were carried out in class and all of the student contributions were injected into the pre-constructed eZoomBook template.

The teacher first introduced the book using the 'sandwich story' technique (Butzkamm, Caldwell, 2009). This involves telling the story first in French and then gradually introducing more and more layers of English items; after a few readings, the whole story is in English. The teacher in doing so drew attention to the structure and rhymes of the text. 
Although many familiar characters from fairytales were well known to English-speaking children, some of the characters from nursery rhymes were unfamiliar to French children. In this way, French children were introduced to English children's cultural heritage.

Classroom activities were recorded in the tabs of the eZoomBook before the beginning of the workshop, with the exception of only one tab for the student contributions. While the first tab focused on the story itself, the second tab of the eZoomBook (entitled "pictures and names") contained pictures of some characters from the story. Students could listen to the name of each character by clicking on a sound button.

On the third tab (entitled "Rhyming game"), pupils played a simple game to find words which rhyme with the characters. They were then ready to play with more complex elements on page four (entitled "New rhymes") to create new sentences which respect the original rhyming structure of the book. The pupils then choose their own sentences combining characters and situations to collectively create a new version of the story.

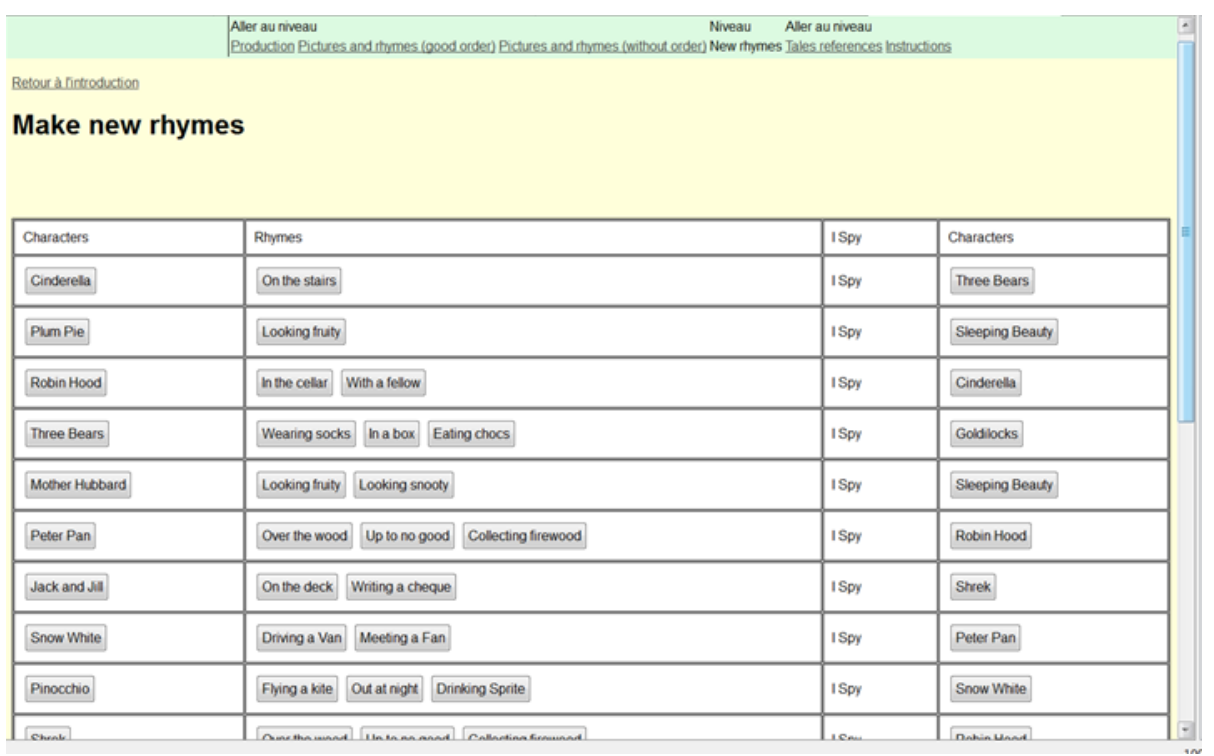

Figure 3. eZB page where pupils can combine characters and rhymes

Each pupil recorded his or her new sentence and illustrated the situation it described. The teacher inserted these illustrations and audio recordings into the first page of the book (Productions). In this way, the pupils contributed to making a new version of the story, which they could re-tell and illustrate themselves.

On the Tales References page, links to videos of all the characters were included, as well as links to videos of the book read aloud with and without the text. The teachers who want to replicate this experience can use these links to introduce the book in class and the pupils can click to listen to the story at home. The instructions tab contains all the instructions for teachers.

This example illustrates the development of an eZoomBook with a pre-constructed structure and guidelines.

\section{High school students: "Symbolism" (French program)}

The one-term workshop involved a French literature class of ten students. The teacher of this literature class chose to work on an eZoomBook with a pre-constructed structure and guidelines to help the students organize and structure their work. The teacher selected a corpus of 16 texts to study. The student input (work on vocabulary, text analysis, comments) was pre-defined, and the class activities required students to work outside class. Each student worked on his or her individual eZB, with all of the eZBs merged into one at the end of the semester.

The teacher's objective was to work on a corpus of texts around the theme of the 'femme fatale' and to teach students how to organize their note-taking in an eZB, which included the texts studied as well as seven tabs relating to students' research and note-taking.

The structure of the eZB was a matrix structure designed by the teacher: 


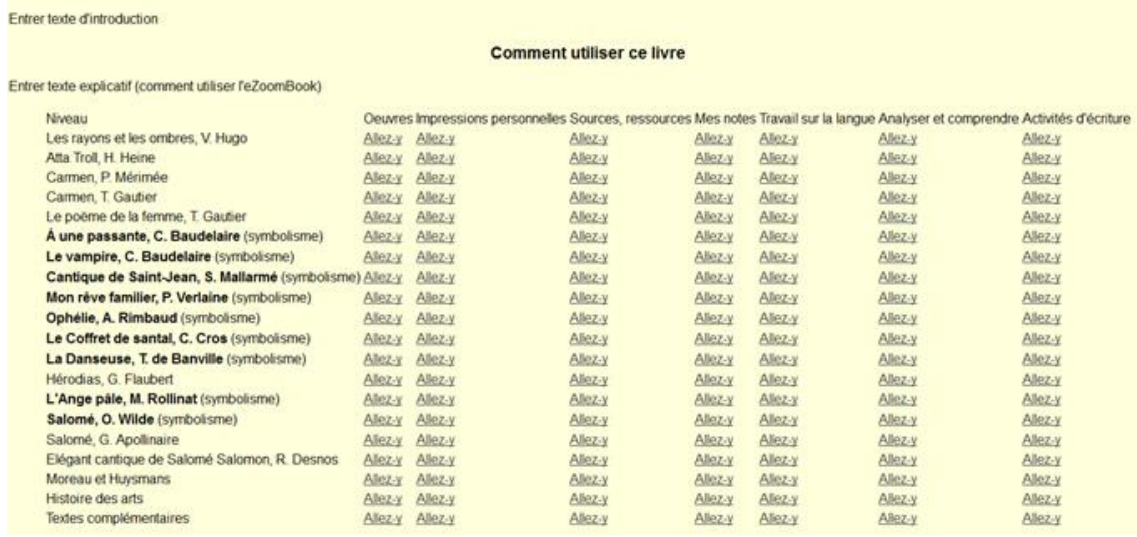

Figure 4. Matrix structure of eZB

On the axis of the ordinate, the teacher placed the 12 texts around the theme of the femme fatale.

On the abscissa, the teacher selected seven tabs for the student activities:

- Works chosen: original texts such as "À une passante", "Le vampire" (C. Baudelaire), "Cantique de Saint-Jean" (S. Mallarmé), "Mon rêve familier" (P. Verlaine), "Ophélie" (A. Rimbaud).

- Personal impressions: first impressions of students reading the proposed texts;

- Sources, resources: the sources given by the teacher and supplemented by those that the students search on their own;

- My notes: notes written by students about work in progress;

- Language work: remarks on language or vocabulary;

- Analysis and comprehension: student analysis work, often driven by the teacher's presentation;

- Writing activities: written work requested by the teacher.

In the classroom instruction, the French teacher navigated freely between different tasks that she had given to the students (search for information, writing, reading, presentations), and she encouraged them to collect everything in their individual eZBs. She also guided the students in their note taking and gave them advice on how to structure their notes.

\section{French Engineering students: "Shakespeare elective" (English program)}

The twenty students participating in the workshop had signed up for an elective Shakespeare literature class as part of their English as a Foreign Language requirement. The students were French undergraduate engineering students having studied English in secondary school for over ten years. Students had an advanced level in terms of everyday English, but they had never had to read works of literature extensively. They were highly skilled in using new technologies and were especially motivated to use the eZB tool in their assignments. However, they were somewhat apprehensive about having to read plays and, in particular, Shakespeare's plays. The project aimed to demystify the reading task through a different presentation mode (electronic and not paper) and give readers more control over the level of difficulty (the zooming in and out function coupled with learning enhancements).

The material covered included both Shakespeare's comedies and tragedies. After several teacher-led classroom sessions on the background to Shakespeare's plays had taken place including several extracts of cinematographic adaptations, the eZB task was presented to students: to collaboratively create an enriched version of Romeo and Juliet. Possibilities for multimedia enrichments included links to different theatrical interpretations of scenes on YouTube or multimedia sequences produced by the students themselves. At the end of the semester, the teacher uploaded the eZB on the University's intranet.

The following tabs on the eZB template were the architecture for building the eZB and students were assigned sections of the play. They summarized the material within the tabs and searched for potential enrichments of the text:

- Summary tab: selection of quotes and summary lines to link them.

- Comprehension question tab: text-related questions ("What happens when Romeo spots Juliet for the first time?"). 
- Old English/Modern English tab.

- Multimedia enrichment tabs (links to Shakespeare scenes on YouTube, teacher resource sites, such as: https://www.tes.com/teaching-shakespeare/?utm_campaign=GB-RES691, etc.)

- Critical commentaries tab

Internet sources guided the students in selecting the content for the above tabs. Students were encouraged to explore, sample, and choose the resources that were meaningful to them. Here the information search process was one of the learning goals as students learned how to make effective use of the information sources available and collaboratively make judgments about the pertinence and quality of what they found on the Internet. Having done that, the students could then write their introduction to their given scenes as well as their comprehension questions, commentaries and quizzes." (Evain, De Marco, 2016a)

This example shows how it is possible to use an eZoomBook with a pre-constructed structure and guidelines, all the while leaving the corpus choice to the students. Indeed, the students chose the specific Shakespeare scenes they wanted to work on and they were responsible for cutting and pasting the text in the eZB. The student input (comparing old and modern English, text analysis, comments, etc.) was pre-defined. Most of the work was in-class. At the end of the semester, students presented their work.

\section{Adult learners in Executive Education: Business English in the workplace}

This project was about stimulating in-class note taking, through a collaborative note-taking document followed by the construction of an eZB at the end of the course. The eZB was a summary document for exam revision as well as a personalizable virtual document (PVD) to keep and to share outside the classroom. This workshop involved ten participants, all colleagues in the same company, who attended an English language course to improve their work-based and professional English-language skills. While aiming to improve English skills generally, the focus was behavioral, that is, to increase the motivation and confidence of the participants in using English at work. The methodology took the form of collaborative note taking on a Google doc, which resulted in an electronic class journal (in eZB format) which students would then be able to take away with them at the end of the course. In total, the finished eZB included the following five tabs or 'chapters': Full Class Journal, Class Profile, News Reviews, Marketing, ERP, Favorite Moments, and Vocabulary.” (Bellay, Evain, De Marco, 2017)

One highly appreciated benefit of the eZB for these adult learners was the possibility for peer-to-peer work similar to the collaborative work they do in the workplace. Stronger students who were able to take notes in English easily helped the weaker students. The stronger trainees were rewarded because the group progressed faster as the teachers corrected their work and offered verbal recognition for their efforts. The blended learning approach was thus fully exploited. Although difficult to measure, teachers also noticed an increase in confidence in using a foreign language.

This example shows how it is possible to create an eZoomBook after the launch and realization of class activities. In this experimentation, the teacher had total freedom to add to the pedagogical content in the course of the semester. The student input (in-class note-taking, marketing exercises, enrichments, etc.) was, in part, pre-defined, but also largely improvised during the course of the semester. Not all of the workshop activities were in-class activities, but the note taking was, and it included a real-time correction on the part of the teacher. The tool made it possible for the teacher to individualize this part of the feedback. The structure of the eZoomBook was defined at the end of the semester in a brainstorming session: the eZoomBook was then created, and the class journal and class work were injected into the eZoomBook.

The examples above show that the potential applications of collective authorship and eZoomBooking are extremely broad: all educational levels, cross-disciplinary projects and group dynamics can benefit from this differentiated methodology.

The appendix below sums up the five experiments in terms of our six variables.

\section{Discussion and Conclusion}

We have shown how six variables mapped out in the below appendix can be matched to our experiments that ranged from primary school pupils to university students. We have chosen to create a table of specifications to show visually the flexibility of the tool in relation to a blended, eclectic methodology. The situations described in this paper have included story-enrichment activities, introduction to English, literary analysis, text-customizations, note taking or diary writing, contrasting and comparing texts, synthesizing, summarizing, and analyzing texts. These situations are not the only ones possible. Future experiments will add different learning contexts and the associated classroom variables. The advantage of the eZB tool is its open-format template adapted to these learning situations in a variety of ways.

The content of each eZB is unique in that it is a student-produced reflection of a teacher-produced plan. Therefore, the 
wide range of possible eZB templates reflects the wide range of teaching approaches in relation to texts and students. The six variables in the above chart constitute a blueprint or decision support tool for teachers while they are mapping out their class projects. It also serves as a template for future pedagogical projects using the eZB tool in that the six-variable chart can be a helpful start for pedagogues who are reflecting on how the eZB can best work for them. Picking and choosing from among the variables or adding other variables is key to the eclectic approach to eZB.

An eZB project allows for made-to-measure pedagogies, which give students and instructor choice in working towards learning objectives. The variables we have isolated were important motivating factors since they insured playing to the strong points of the teacher and students as well as to the opportunities proved by the context of learning.

For each experiment, qualitative and quantitative feedback was collected. The results of the feedback had one element in common: a high level of intrinsic motivation. The student motivation in taking part in these projects was seen in the way the project was actively shared among the participants: within the community of parents in the primary school contexts or uploaded on collaborative sites.

In a blended-learning format, the teacher's role is particularly important in defining the tasks but also in determining the amount of flexibility, managing the classroom atmosphere, and integrating the tool. The process of integrating eZB does not follow a pre-defined recipe. It is the role of the teacher to think about the classroom variables to optimize student responsibility because "each student's role can change along the process but it is essential to establish responsibilities to make sure students learn to work in groups" (Gross, 2007, 7).

The table above illustrates the advantages of the tool, namely that it makes learning visible through the production of PVD's; it facilitates group learning and peer to peer teaching; it allows for flexible and adaptable guidelines. However, along with these benefits come also a constraint on the teacher-student relationship. Using the EZB tool in combination with a variety of approaches requires that the traditional teacher and student roles be revised and viewed not in terms of a top down transmission of knowledge but rather as a partnership in which giving and sharing knowledge is a joint activity.

\section{Acknowledgements}

We would like to thank the ENJEUX program for supporting all of our research activities.

\section{References}

Ahlberg, J., \& Ahlberg, A. (2004). Each peach pear plum. Viking Books.

Bellay, C., Marco, C., \& Evain, C. (2017). eZoomBook Methodology and Template: A Case Study of Collective Authorship in the Classroom. Studies in English Language Teaching, 5. https://doi.org/10.22158/selt.v5n2p231

Brusilovsky, P., Stock, O., \& Strapparava, P. (2000). Adaptive hypermedia and adaptive Web-based systems international conference, AH 2000, Trento, Italy, August 28-30, 2000: proceedings. New York: Springer. Retrieved from http://0-dx.doi.org.fama.us.es/10.1007/3-540-44595-1

Butzkamm, W., \& Caldwell, J. A. W. (2009). The bilingual reform: a paradigm shift in foreign language teaching. Tübingen: Gunter Narr.

Carolan, S., \& Evain, C. (2012, June 7). Skimming content not quality. Retrieved from http://hal.archives-ouvertes.fr/hal-00783578

Carolan, S., Chinesta, F., Evain, C., Magnin, M., \& Moreau, G. (2013). Towards Augmented Learning in Science and Engineering in Higher Education. In Proceedings of the 13th IEEE International Conference on Advanced Learning Technologies (pp. 512-513). IEEE. https://doi.org/10.1109/ICALT.2013.169

Carolan, S., Magnin, M., Evain, C., Moreau, G., \& Chinesta, F. (2012). Developing models for enhanced learning in engineering.

Cassany, D. (2014). Prácticas letradas contemporáneas. México, D.F.: Ríos de tinta.

Evain, C., \& De Marco, C. (2015). Rethinking the promotion of reading through the eZoomBook platform. In INTED 2015 Proceedings (pp. 7926-7933). Madrid.

Evain, C., \& De Marco, C. (2016). Making Teaching Visible to Learners through the eZoomBook Platform. Ubiquitous Learning: An International Journal, 9(3), 31-42. https://doi.org/10.18848/1835-9795/CGP/v09i03/31-42

Evain, C., \& Marco, C. (2014). Reading with a Difference: eZoomBook and MyGame-4. Publishing Research Quarterly, 30(1), 50-62. https://doi.org/10.1007/s12109-014-9352-9

Evain, C., \& Marco, C. (2016a). Teaching Shakespeare in the Digital Age: The eZoomBook Approach. English Language Teaching, 9(6). https://doi.org/10.5539/elt.v9n6p162 
Evain, C., \& Marco, C. (2016b). The myplace4u Platform Project: A Tool for Place Branding and the Promotion of Literature. Springer Publishing Research Quarterly, 32(2), 103-112. https://doi.org/10.1007/s12109-016-9449-4

Evain, C., Carolan, S., \& Magnin, M. (2012). Preparing for Generation Z: The Hippocampus Experiment at the Ecole Centrale de Nantes. In Proceedings of the ASME 11th Biennial Conference. Nantes: ESDA. https://doi.org/10.1115/ESDA2012-82034

Evain, C., DeMarco, C., \& Carolan, S. (2013). Le nouveau dispositif «eZoomBook» : perspectives pédagogiques. Distances, Médiations et Savoir, 1, 1-17. https://doi.org/10.4000/dms.337

Falquet, G., \& Ziswiler, J. C. (2005). A Virtual Hyperbooks Model to Support Collaborative Learning. INTERNATIONAL JOURNAL ON E LEARNING, 4(1), 39-56.

Gilles, F., Luka, N., \& Jean-Claude, Z. Proceedings of the fifteenth ACM conference / Hypertext and hypermedia (HYPERTEXT '04). (2004). Towards digital libraries of virtual hyperbooks. ACM, 2 Penn Plaza, Suite 701, New York, NY 10121-0701, USA. https://doi.org/10.1145/1012807.1012815

Gross, B. (2007). El aprendizaje colaborativo a través de la Red: límites y posibilidades. Revista Aula de Innovación Educativa, (162), 44-50. https://doi.org/10.4000/dms.337

Grzega, J., \& Schoner, M. (2008). The didactic model LdL (Lernen durch Lehren) as a way of preparing students for communication in a knowledge society. Journal of Education for Teaching, 34(3), 167-175. https://doi.org/10.1080/02607470802212157

Hattie, J. (2009). Visible learning a synthesis of over 800 meta-analyses relating to achievement. London; New York: Routledge.

Hattie, J. (2011). Visible Learning for Teachers \& Students: Maximizing impact on learning. S.1.: Taylor \& Francis.

Hattie, J., \& Yates, G. (2014). Visible learning and the science of how we learn. London; New York: Routledge, Taylor $\&$ Francis Group.

Johnson, D. W., \& Johnson, R. T. (2008). Training for Cooperative Group Work, 167-183.

Kahle, B. (2007). The Open Library. Project Gutenberg. Retrieved from http://www.gutenberg.org/ebooks/23904

Laurillard, D. (2012). Teaching as a design science: building pedagogical patterns for learning and technology. New York, NY: Routledge.

Laurillard, D., University of London, \& Institute of Education. (2008). Digital technologies and their role in achieving our ambitions for education. London: University of London, Institute of Education.

Lindberg, J. O., Olofsson, A. D., \& Stödberg, U. (2010). Signs for learning to perform in a digital environment. Australasian Journal of Educational Technology, 26(7). https://doi.org/10.14742/ajet.1030

Martin, J. P. (1985). Zum Aufbau didaktischer Teilkompetenzen beim Schüler Fremdsprachenunterricht auf der lerntheoretischen Basis des Informationsverarbeitungsansatzes. Gunter Narr Verlag, Tübingen.

Romainville, M., \& Michaut, C. (2012). Réussite, échec et abandon dans l'enseignement supérieur. Bruxelles: De Boeck.

\section{Notes}

Note 1. In addition to the focus on human sciences here, eZB has also been further developed for didactic applications in the hard sciences. See for example Simon Carolan's work on the subject (Carolan, Evain, Chinesta, Magnin, and Moreau, 2013). 


\section{Appendix}

Complete mapping of five eZB workshops along six classroom variables:

\begin{tabular}{|c|c|c|c|c|c|c|}
\hline $\begin{array}{l}\text { Classroom } \\
\text { variables } \\
\text { Learning } \\
\text { context }\end{array}$ & $\begin{array}{lr}\text { Corpus } & \text { of } \\
\text { original } & \text { text(s) } \\
\text { for } & \text { course } \\
\text { content } & \\
\end{array}$ & $\begin{array}{l}\text { Structure } \\
\text { and guidelines }\end{array}$ & Student input & $\begin{array}{l}\text { In-class or } \\
\text { homework }\end{array}$ & $\begin{array}{l}\text { Single or } \\
\text { multi- } \\
\text { disciplinary }\end{array}$ & $\begin{array}{l}\text { Type of final eZB } \\
\text { output }\end{array}$ \\
\hline $\begin{array}{l}\text { Primary } \\
\text { School : } \\
\text { "The Wolf } \\
\text { and the } \\
\text { Lamb" } \\
\text { (French } \\
\text { program) }\end{array}$ & $\begin{array}{l}\text { Four texts: } \\
\text { rewritings of } \\
\text { the fable "The } \\
\text { Wolf and the } \\
\text { Lamb" }\end{array}$ & Pre-constructed & $\begin{array}{l}\text { Improvized: } \\
\text { - rewriting of the } \\
\text { story } \\
\text { - illustrations } \\
\text {-recordings, etc. }\end{array}$ & All in class & $\begin{array}{l}\text { French } \\
\text { literature and } \\
\text { exposure to } \\
\text { foreign } \\
\text { languages }\end{array}$ & $\begin{array}{l}\text { Collaborative eZB } \\
\text { Constructed at the } \\
\text { end of the semester }\end{array}$ \\
\hline $\begin{array}{l}\text { Primary } \\
\text { School: } \\
\text { "Each Peach } \\
\text { Pear Plum" } \\
\text { (English } \\
\text { program) }\end{array}$ & $\begin{array}{l}\text { One book: } \\
\text { Each Peach } \\
\text { Pear Plum }\end{array}$ & $\begin{array}{l}\text { Brainstorming } \\
\text { at the end of the } \\
\text { project }\end{array}$ & $\begin{array}{l}\text { Pre-defined: } \\
\text { - } \\
\text { rhyme-matching } \\
\text { game } \\
\text { - illustrations } \\
\text {-recordings, etc. }\end{array}$ & All in class & English & $\begin{array}{l}\text { All student } \\
\text { contributions were } \\
\text { injected into a } \\
\text { pre-constructed } \\
\text { collaborative eZB }\end{array}$ \\
\hline $\begin{array}{l}\text { High school: } \\
\text { "Symbolism" } \\
\text { (French } \\
\text { program) }\end{array}$ & 16 texts & Pre-constructed & $\begin{array}{l}\text { Pre-defined: } \\
\text { - work on } \\
\text { vocabulary } \\
\text { - text analysis } \\
\text { - comments, etc. }\end{array}$ & $\begin{array}{l}\text { Blended } \\
\text { learning }\end{array}$ & $\begin{array}{l}\text { French } \\
\text { literature }\end{array}$ & $\begin{array}{l}\text { Individual eZBs } \\
\text { gathered for a } \\
\text { collaborative eZB }\end{array}$ \\
\hline $\begin{array}{l}\text { University } \\
\text { Centrale } \\
\text { Nantes: } \\
\text { "Shakespeare } \\
\text { elective" } \\
\text { (English } \\
\text { program) }\end{array}$ & $\begin{array}{l}\text { Extracts from } \\
\text { Shakespeare's } \\
\text { plays }\end{array}$ & Pre-constructed & $\begin{array}{l}\text { Pre-defined: } \\
\text { - comparing old } \\
\text { and modern } \\
\text { English } \\
\text { - text analysis } \\
\text { - comments, etc. }\end{array}$ & $\begin{array}{l}\text { Blended } \\
\text { learning }\end{array}$ & $\begin{array}{l}\text { English } \\
\text { literature }\end{array}$ & $\begin{array}{l}\text { All student } \\
\text { contributions were } \\
\text { injected into a } \\
\text { pre-constructed } \\
\text { collaborative eZB }\end{array}$ \\
\hline $\begin{array}{l}\text { Executive } \\
\text { Education: } \\
\text { Business } \\
\text { English in } \\
\text { the } \\
\text { workplace }\end{array}$ & $\begin{array}{l}\text { In-class } \\
\text { note-taking }\end{array}$ & $\begin{array}{l}\text { Brainstorming } \\
\text { at the end of the } \\
\text { project }\end{array}$ & $\begin{array}{l}\text { Improvized: } \\
\text { - in-class } \\
\text { note-taking } \\
\text { - marketing } \\
\text { exercises, } \\
\text { - enrichments, } \\
\text { etc. }\end{array}$ & $\begin{array}{l}\text { Blended } \\
\text { learning }\end{array}$ & $\begin{array}{l}\text { Business } \\
\text { studies }\end{array}$ & $\begin{array}{l}\text { The students' } \\
\text { google-doc } \\
\text { contributions were } \\
\text { injected into a } \\
\text { collaborative eZB } \\
\text { which was } \\
\text { constructed at the } \\
\text { end of the project }\end{array}$ \\
\hline
\end{tabular}

\section{Copyrights}

Copyright for this article is retained by the author(s), with first publication rights granted to the journal.

This is an open-access article distributed under the terms and conditions of the Creative Commons Attribution license which permits unrestricted use, distribution, and reproduction in any medium, provided the original work is properly cited. 